\title{
小児用シロップ斉の粘度と計量器への 付着損失との定量的関係
}

\author{
山本佳久 ${ }^{1}$, 鈴木豊史 ${ }^{* 2}$, 深水啓朗 ${ }^{2}$, 鎌野 衛 $^{1}$, 伴野和夫 ${ }^{2}$ \\ 有限会社若葉調剂薬局桜木薬局 ${ }^{1}$ \\ 日本大学薬学部薬剂学研究ユニット ${ }^{2}$
}

\section{Quantitative Relationship between Adhesion Loss of Syrups for Infants in a Metering Glass and Their Rheological Characteristics}

\author{
Yoshihisa Yamamoto ${ }^{1}$, Toyofumi Suzuki ${ }^{2}$, Toshiro Fukami ${ }^{2}$, \\ Mamoru Kamano ${ }^{1}$ and Kazuo Tomono ${ }^{2}$ \\ Sakuragi Pharmacy, Wakaba Pharmacy Co. Ltd. ${ }^{1}$ \\ Research Unit of Pharmaceutics, College of Pharmacy, Nihon University ${ }^{2}$ \\ $\left[\begin{array}{l}\text { Received December } 252007 \\ \text { A ccepted March 25, } 2008\end{array}\right]$
}

We determined the adhesion loss in a metering glass for 9 types of syrup for infants, and investigated the relationship between the adhesion loss and the rheological properties of the syrups. There was a good correlation $\left(r^{2}=0.981\right)$ between the viscosity of the syrups and percentage syrup residues on the metering glass. Further, from the viewpoints of accuracy and efficiency in dispensing, our finding that percentage residues for a dispenser were much lower $(<0.15 \%)$ than for the metering glass suggested that it was better to use a dispenser for dispensing viscous syrups with a viscosity of at least 50-60 $\mathrm{mPa} \cdot \mathrm{s}$. The results of our examination of syrup viscosities in the present study are expected to be useful information for their administration, and to contribute to the establishment of dispensing procedures based on scientific evidence.

Key words — syrups, viscosity, metering glass, adhesion loss, dispenser

緒言

多くの薬斉師は, 計量器具に対する付着残存性が高い シロップ斉があることを，投薬びんへの薬液の移行過程 を通じて経験している . 小児の患者からの処方せんを応 需している薬局においては, シロップ斉を調剂する頻度 が比較的高い . シロップ斉の秤量には, 一般にメートグ ラス , ディスペンサーおよび滴びんなどの計量器が用い られているが, なかでもメートグラスは使いやすさの点 から，薬局で最も繁用されている計量器の一つであ $3^{11}$. 計量器具内に薬液が付着残存する要因の一つにシ ロップ剂固有の粘度が挙げられる．しかしながら，イン タビューフォーム(IF)の「 $「 \mathrm{pH}$, 浸透圧比, 粘度, 比重, 無菌の旨および安定な $\mathrm{pH}$ 域等」の項に，粘性の指標と
なる粘度あるいは動粘度が記載されているシロップ剂は 一部に過ぎない．また，IFの「斉形の区別および性状」 の項より，「粘稠な液体」や「濃稠な液体」などの粘性 を有していることか理解できるシロップ斉もあるが，こ れら粘性の記述に明確な基準はない、「調斉指針」によ れば，「粘稠性の内用液剂およびTDM 対象薬剂である エリキシル剂を秤量する場合にはディスペンサーを使用 すると正確に移し出すことができて，正確な調剤を行う ことができる」とされている11.しかしながら，ディス ペンサーの使用が推奨される「粘稠性」に関する基準の 規定はなく，メートグラス内に付着残存性が高いシロッ フ剤の調斉に注意を払うことは，薬剤師の経験や感覚に 頼らざるを得ない現状である 一方 粘稠性の高いシロッ プ斉は，乳幼児の服用性に対して影響を与えることが予 想される . シロップ斉は数種類の混合で処方されるケー 
スが多く，服用性の観点からも混合シロップ斉の粘性に 関する情報を予測することが重要である．

そこでわれわれは, シロップ斉のメートグラス内薬液 付着残存性を評価し, 光の付着損失とレオロジー的性質 との関連性について検証した .さらに, 調斉時に計量器 具を選択する際に有用な「粘稠性」の基準について提案 し，実際に処方された混合シロップ斉の粘性を予測する ことから，弚の服用性について考察した .

\section{方法}

\section{1. 使用薬剂}

アスベリンシシロップ 0.5\%(以下，アスベリンと略す) は田辺製薬株式会社，アタラックス ${ }^{\circledR}-P$ アロップ 0.5\% (以下, アタラックスと略す)はファイザー株式会社 , カ ロナール シロロップ $2 \%$ (以下 , カロナールと略す)は昭和 薬品化工株式会社，ゼスランシロッップ $0.03 \%$ (以下 , ゼ スランと略す)は旭化成ファーマ株式会社, 精製水は日 医工株式会社, 単シロップはメルク製薬株式会社, ノイ

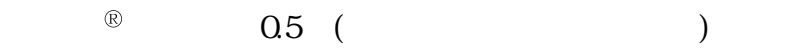

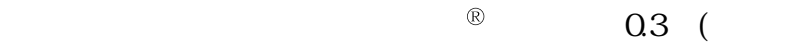
ムコソルバンと略す)は帝人ファーマ株式会社，ムコダ イン ${ }^{\circledR}$ シップ $5 \%$ (以下，ムコダインと略す)は杏林製薬 株式会社, メプチン・シロップ $5 \mathrm{\mu g} / \mathrm{mL}$ 0.0005\%(以下， メプチンと略す)は大塚製薬株式会社, ペリアクチンシ ロップ 0.04\%(以下, ペリアクチンと略す)は萬有製薬株

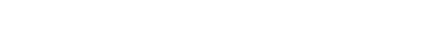

\section{2. メートグラス内付着残存率の測定}

メートグラス(円錐型液量計 $30 \mathrm{~mL}$, Climbing Corpora tion)の質量を量った後, 試料 $10 \mathrm{~mL}$ をメートグラス内に 秤取し，弚の質量を測定した。試料の入ったメートグラ スを一定速度で約 1秒かけて水平(メートグラスの口側 平面を垂直)にし，光の後 10 秒間この状態を維持するこ とにより，試料を投薬びんのなかに流下させた(図 1). 10秒経過後, 試料移行後のメートグラスの質量を測定 した，質量は電気式はかり(DJH-300，新光電子(株))で 測定し, 試験は室温約 $25^{\circ} \mathrm{C}$ にコントロールされた薬局 調剂室内において実施した .メートグラス内付着残存率 (\%)は式(1)により算出した . 試料が混合阂の場合 , 傾倒 混和を 10 回行った後に付着残存率の測定を行った .

$$
R_{m}=\left\{\frac{\left(W_{s}^{\prime}-W\right)}{\left(W_{s}-W\right)}\right\} \times 100
$$

ここで， $\mathrm{R}_{\mathrm{m}}$ はメートグラス内付着残存率 $(\%), \mathrm{W}$ は メートグラスの質量(g)，Wsは $10 \mathrm{~mL}$ の試料の含まれた メートグラスの質量(g)，Wś は残存した試料が含まれ たメートグラスの質量(g)を光れ光れ示している.
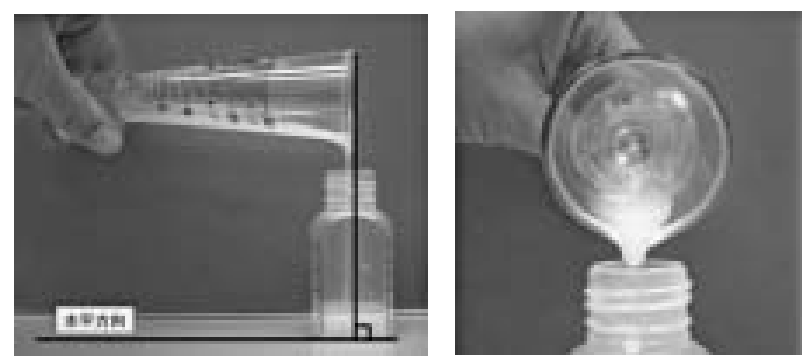

図 1. シロップ剂のメートグラス内付着残存率の測定法

付着残存率の時間推移はメートグラスを水平にしてか ら，5，10，30，60および 120 秒間，弚の状態を維持す ることにより測定した .

\section{3. 粘度の測定 ${ }^{2)}$}

試料の粘度は回転粘度計(B 型粘度計 $\mathrm{BL}$ ，(株)東京計 器)を用いて測定した . 室温付近の温度 $\left(25^{\circ} \mathrm{C} \pm 1\right)$ で試料 中のロータを一定速度で回転(6〜60 rpm)させたときに， ロータに働く粘性抵抗トルク值を測定した. 低粘度( $<15$ $\mathrm{mPa} \cdot \mathrm{s})$ の場合には, 7.2 72 $\mathrm{s}^{-1}$ の範囲で, 弚れ以上の粘 度の場合には, 1.7 17 s ${ }^{-1}$ の範囲で粘度計のロータや光 の回転数を変えることによりせん断速度を上昇させ，光 のときのせん断応力をプロットした . 回帰直線が原点を 通る直線となるニュートン流動を示した場合，粘度はレ オグラムの直線の傾きと式(2)の関係より算出した .

$$
\mathrm{D}=1 / \mathrm{n}
$$

ここで，Sはせん断応力 $(\mathrm{mPa}), \mathrm{D}$ はせん断速度 $\left(\mathrm{s}^{-1}\right)$

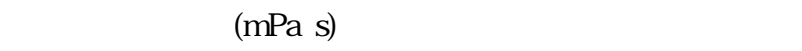
ラムの直線が原点を通らず，せん断応力軸と交わる塑性 流動を示した場合，式(3)から塑性粘度门を算出し，こ の数值を用いて他㓢の粘度との比較に用いた .

$$
\mathrm{D}=1 / \mathrm{r}\left(\mathrm{S}-\mathrm{S}_{0}\right)
$$

ここで, グは塑性粘度 $(\mathrm{mPa} \cdot \mathrm{s}), \mathrm{S}$ （は回帰直線とせん 断応力軸との交点, すなわち降伏值 $(\mathrm{mPa})$ を兴れ艺れ示 す。

\section{4. 密度の測定 ${ }^{3)}$}

試料の密度は, ピクノメーター(比重びん)を用いて測 定した . 比重びんの全質量をあらかじめ量り，一定体積 $(5 \mathrm{~mL})$ の試料を比重びんに満たし，250 の恒温槽で試 料温度を安定させた後, 天秤で光の質量を測定した。密 度は式(4)から算出した。

$$
\rho=\frac{\left(W_{s}-W\right)}{\left(W_{w}-W\right) / \rho_{w}}
$$

ここで， $\rho$ は密度 $(\mathrm{g} / \mathrm{mL}), W_{\mathrm{s}}$ および $\mathrm{W}_{\mathrm{w}}$ は試料およ び水の質量(g), W はピクノメーターの質量(g)， $\rho \mathrm{w}$ は 
水の密度 $\left(0.99704 \mathrm{~g} / \mathrm{mL} ， 25^{\circ} \mathrm{C}\right)$ を弚れ艺れ示している。

\section{5. 動粘度の算出}

試料の動粘度は, 粘度を同温度 $\left(25^{\circ} \mathrm{C}\right)$ の弚の試料の密 度を用いて，式(5)から算出した。

$v=n / \rho$

ここで, $、$ は動粘度 $\left(\mathrm{mm}^{2} / \mathrm{s}\right)$ を示している．

\section{6. 接触角の測定 ${ }^{4}$}

試料の接触角 $\theta$ は，液滴法により室温付近の温度(25 ${ }^{\circ} \mathrm{C} \pm 1$ 1)で測定した . 重力の影響を無視できる液滴量であ る試料 $5 \mu \mathrm{L}$ をガラス平板表面上に滴下し，30秒後の液 滴画像をマイクロカメラ(CCD-S 2, (株)島津製作所)で 撮影し，固体 - 液体界面(ガラス表面の水平線)に対する 液滴の端点と頂点を結心゙直線の角度 $\theta / 2$ を visual scalar (MCP-550，Scopeman，(株)モリテックス)を用いて計測 した .

\section{7. ディスペンサー内付着残存率の測定}

本研究ではディスペンサーとして注射用シリンジ(10 $\mathrm{mL}$ ，テルモ(株))を使用した . シリンジの質量を量った 後, 試料 $10 \mathrm{~mL}$ をメートグラス内に吸引し, 关の質量 を測定した . 試料の入ったシリンジを投薬びんに移行さ せ , 試料移行後のシリンジの質量を測定した .ディスペ ンサー内付着残存率は式(6)から算出した .

$$
R_{d}=\left\{\frac{\left(W_{d}^{-}-W\right)}{\left(W_{d}-W\right)}\right\} \times 100
$$

ここで， $R_{d}$ はディスペンサー内付着残存率 $(\%), W$ はディスペンサーの質量(g)，W $\mathrm{W}$ は $10 \mathrm{~mL}$ の試料の含ま れたディスペンサーの質量(g)，Wd

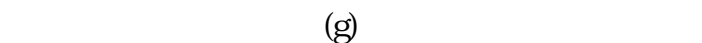

\section{8. 統計解析}

有意差検定は一元配置の分散分析(ANOVA)後, Fishertestを用いて行い， $p<0.05$ のとき有意差ありとした .

\section{結果}

1. シロップ斉のメートグラス内付着残存性

試料 $10 \mathrm{~mL}$ を秤取したメートグラスを 10 秒間水平に 維持したときのシロップ斉のメートグラス内付着残存率 は光れ光れ精製水 $1.57 \pm 0.25 \%$ (平均值 標準偏差, $n=$ 3) , アタラックス $18.26 \pm 4.08 \%$,単シロップ11.26士 1.68

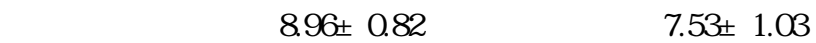

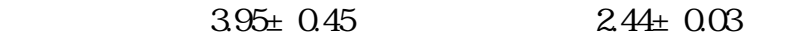
ムコダイン $2.42 \pm 0.38 \%$ ，ペリアクチン $2.37 \pm 0.24 \%$ ， ノイチーム $2.10 \pm 0.42 \%$ 光してメプチン $1.99 \pm 0.23 \%$ であった .このうち, アタラックス , 単シロップ , ムコ ソルバンおよびアスベリンは, 精製水と比較して有意に 高い值を示した(図 2)。

\section{2. 付着残存率の時間推移}

精製水に対して有意に高い付着残存率を示したアタ ラックス, 単シロップ , ムコソルバンおよびアスベリン について , メートグラス内付着残存率の時間推移につい て検討した．図 3 に示すように，弚れらの付着残存率は メートグラスを水平に維持した時間の延長にともない減 少し，120秒間メートグラスを水平に維持した時におい ては 5 種のシロップ斉すべての付着残存率が $5 \%$ 以内に 収束した。

\section{3. シロップ斉の粘度}

検討に使用した小児用シロップ斉について，せん断速 度 $\mathrm{D}$ とせん断応力 $\mathrm{S}$ との関係を示すレオグラムを図 4 に示す. せん断速度 $\mathrm{D}$ がせん断応力 $\mathrm{S} に$ 比例する

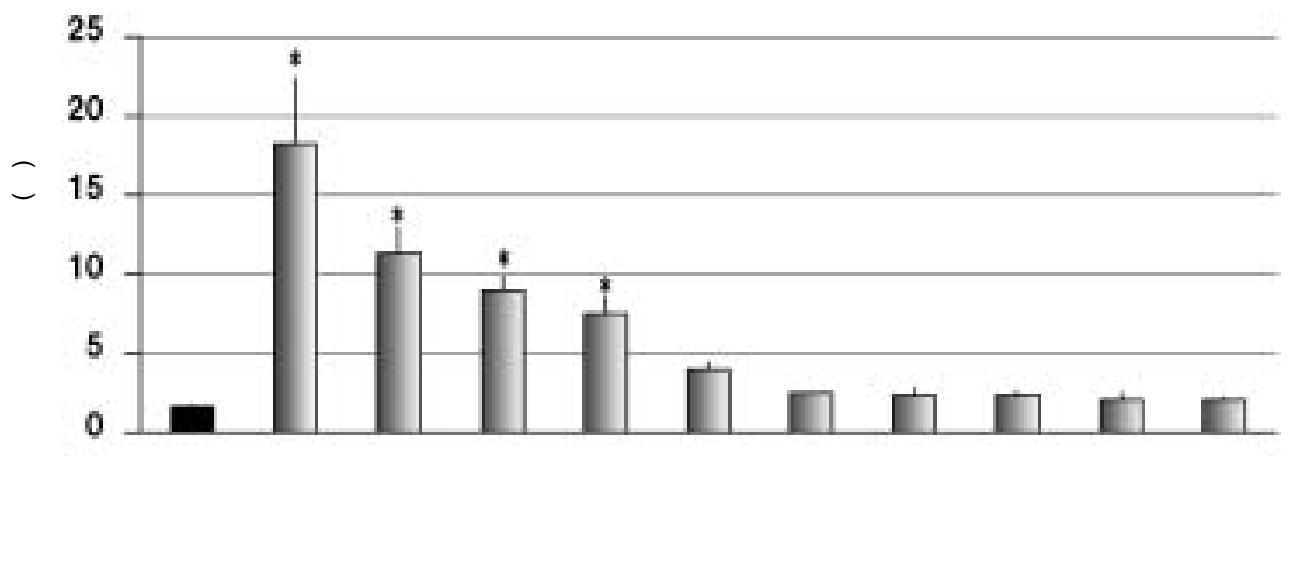

図 2 . シロップ斉のメートグラス内付着残存率 . 平均値 \pm 標準偏差 $(n=3)$. ${ }^{*} \mathrm{p}<0.05$ vs 精製水 


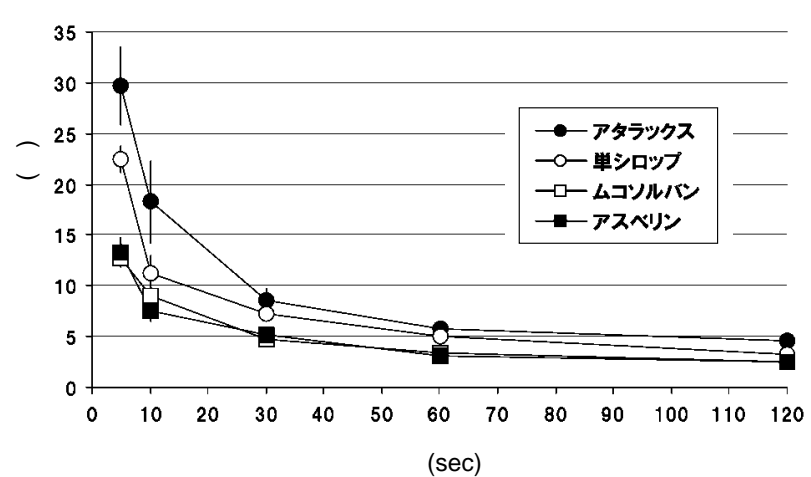

図 3.メートグラス内付着残存率の時間推移 . 平均值 \pm 標準偏差 $(n=3)$.

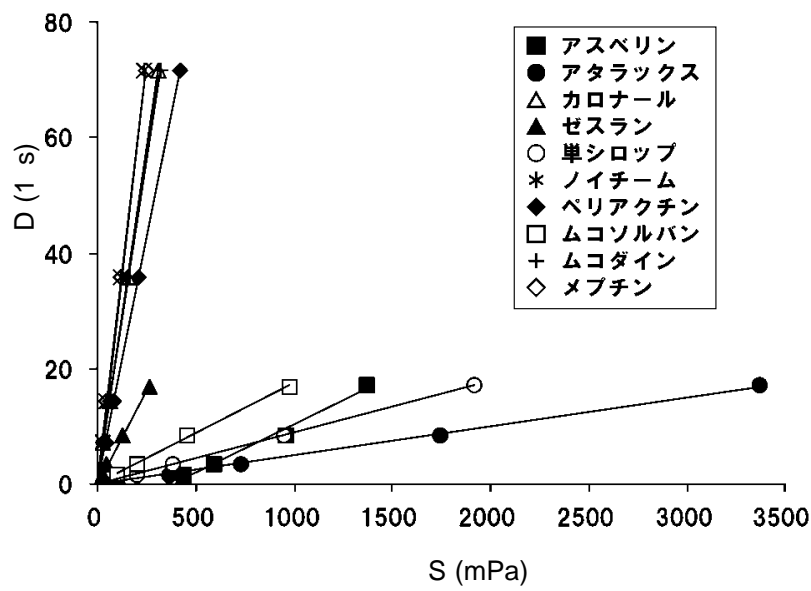

図 4 . シロップ斉におけるせん断速度とせん断応力 の関係(レオグラム)

ニュートン液体の D-S 曲線は原点を通る直線として表 される(式(2)) . アスベリンのD-S曲線は，降伏值が約 $400 \mathrm{mPa}$ となる塑性流動を示したのに対し，他の薬剤に おいてはいずれもニュートン流動を示すことがわかっ
た . 表 1 に示すようにアタラックスおよび単シロップの 粘度は $100 \mathrm{mPa} \cdot \mathrm{s}$ 以上であり，アアスベリンとムコソルバ ンはほぼ同程度(約 $60 \mathrm{mPa} \cdot \mathrm{s})$ の粘度であった . 谷の他 6 種のシロップ斉は $15 \mathrm{mPa} \cdot s$ 以下の粘度であり，今回検 討したシロップ斉のなかでは比較的低粘度であった 。

4. シロップ斉の密度，動粘度および接触角 シロップ刘の密度は, アスベリンの $1.08 \mathrm{~g} / \mathrm{mL}$ から単 シロップの $1.32 \mathrm{~g} / \mathrm{mL}$ の範囲内であった . 算出した動粘 度は,いずれのシロップ斉も粘度と同樣な順を示した(表 1) . ガラス材質とシロップ斉のぬれ性を評価するため に, 平らなガラス表面に滴下したシロップ斉の液滴がガ ラス板と接触する角度を測定した。試料の蒸発・揮発防 止と内用液剂の調剂時間を考慮して評価した滴下 30 秒 後の接触角を表 1 に示す . 検討した小児用シロップ斉の なかでは, 単シロップおよびアタラックスが比較的高い 接触角(約 20 deg.)を示したのに対して，低濃度(0.0005\%) であるメプチンが低い接触角(約 4 deg.)を示すことがわ かった . 光の他 7 種のシロップ剂は 10〜17 deg.の範囲 内の接触角を示し , メプチンを除き今回検討したシロッ プ斉の接触角はほぼ同程度の值であった .

5. シロップ斉のメートグラス内付着残存率と粘度，密 度および接触角との関係

シロップ斉 $10 \mathrm{~mL}$ を含むメートグラスを 10 秒間水平 に維持したときのシロップ斉のメートグラス内付着残存 率と光の粘度(a)および動粘度(b)との関係は, 良好な正 の相関性が認められた(粘度 $r^{2}=0.981$, 動粘度 $r^{2}=$ 0.987，図 5). これに対して，付着残存率と接触角(c)お よび密度 $(d)$ との間に良好な関係はみられなかった(接触 角 $r^{2}=0.400$, 密度 $\left.r^{2}=0.417\right)$.

表 1. シロップ剂の粘度, 密度, 動粘度および接触角

\begin{tabular}{|c|c|c|c|c|}
\hline シロッフ用 & $\begin{array}{c}\text { 粘度 }^{\mathrm{a})} \\
(\mathrm{mPa} \cdot \mathrm{s})\end{array}$ & $\begin{array}{c}\begin{array}{c}\text { 密 度 } \\
(\mathrm{g} / \mathrm{mL})\end{array}\end{array}$ & $\begin{array}{l}\text { 動粘度 }^{\mathrm{b})} \\
\left(\mathrm{mm}^{2} / \mathrm{s}\right)\end{array}$ & $\begin{array}{l}\text { 接触角 } \\
\text { (deg.) }\end{array}$ \\
\hline アスベリン & 60.6 & 1.08 & 55.9 & 12.8 \\
\hline アタラックス & 200 & 1.28 & 156 & 19.4 \\
\hline カロナール & 4.32 & 1.12 & 3.88 & 12.0 \\
\hline ゼスラン & 15.7 & 1.22 & 12.8 & 15.1 \\
\hline 単シロップ & 112 & 1.32 & 85.3 & 20.8 \\
\hline ハイチーム & 3.33 & 1.13 & 2.94 & 16.9 \\
\hline ベリアクチン & 5.86 & 1.15 & 5.10 & 13.0 \\
\hline ムコソルハシ & 57.8 & 1.15 & 50.2 & 13.0 \\
\hline ムコダイン & 4.47 & 1.17 & 3.83 & 10.7 \\
\hline xプチン & 3.40 & 1.14 & 2.99 & 3.86 \\
\hline
\end{tabular}

a) 粘度は, シロップ剂のせん断速度Dとせん断応力S との関係(図 4)から式(1)を用いて算出した 値を示す。

b) 動粘度は,粘度を同温度 $\left(25^{\circ} \mathrm{C}\right)$ のシロップ剂の密度で除した值を示す。 
(a)

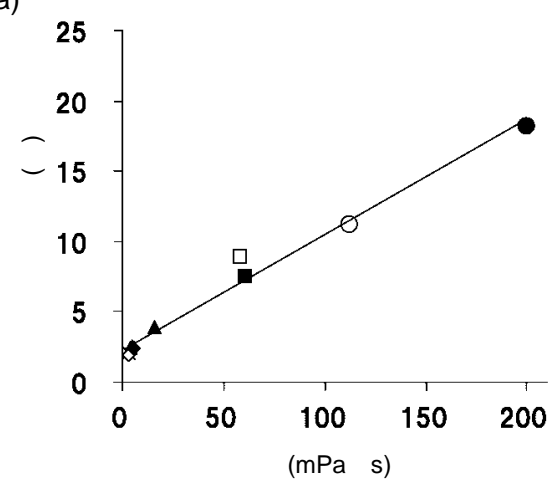

(c)

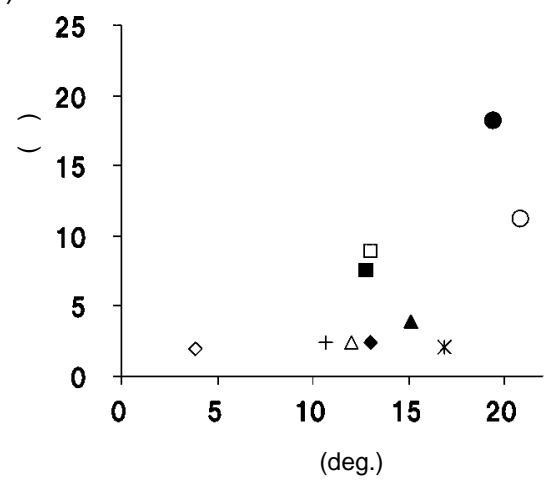

(b)

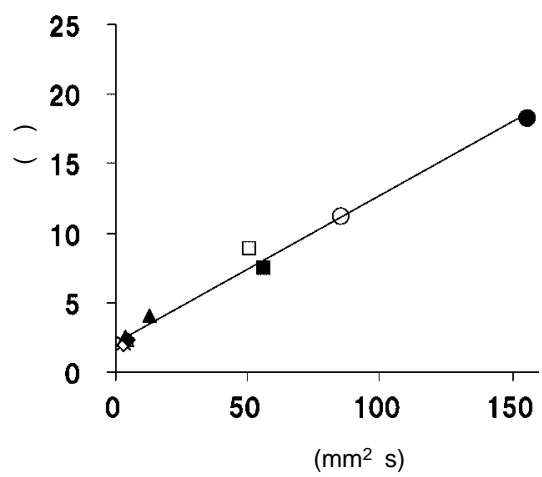

(d)

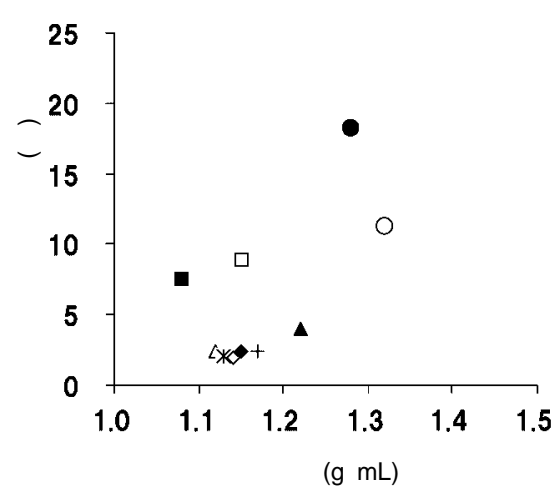

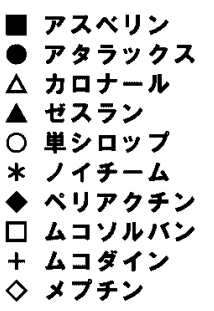

図 5.メートグラス内付着残存率と(a)粘度，(b)動粘度，(c)接触角および (d)密度との関係
6. シロップ斉のディスペンサー内付着残存率

表 2 に示すように , ディスペンサー内付着残存率はア タラックス , 単シロップ , アスベリンおよびムコソルバ ンにおいて 0.15\% 以下であり,メートグラスで秤量す る場合と比較して，きわめて低い付着残存率を示した .

\section{7. 混合シロップ斉のメートグラス内付着残存率}

混合シロップ斉の粘性を把握する目的で , 実処方 4例 におけるメートグラス内付着残存率の測定を行った . Rp 1 と 2 は高粘度(アスベリンおよびムコソルバン)と 低粘度のシロップ剂の混合物，Rp .3は高粘度のシロッ プ剂を含まない例である．Rp 1〜3における付着残存率 は $3.5 \%$ 以下であったが, 高粘度のアスベリンとムコソ
ルバンだけ含む Rp .4においては, 他の Rp .1〜3 と比較 してわずかに高い付着残存率(5.5\%)を示した(表 3) .

考察

今回の検討で用いたシロップ斉の $\mid \mathrm{F}^{5-13}$ において， $\ulcorner\mathrm{pH}$, 浸透圧比, 粘度, 比重, 無菌の旨および安定な $\mathrm{pH}$ 域等」(製剂に関する項目)の項に粘度に関する記載が あったのは，9品目中アスベリン，アタラックス，ゼス ラン , ノイチームおよびペリアクチンの 5 品目のみで あった(表 4)．また，「剂形の区別および性状」(製剂に関 する項目)の項に粘性に関する記述のあるシロップ剂 は，ゼスラン(濃稠)およびメプチン(やや粘稠)の 2 品目

表 2. シロップ刘のディスペンサー内付着残存率

\begin{tabular}{|c|c|c|c|}
\hline シロツフ绪 & $\begin{array}{c}\text { 粘度 } \\
(\mathrm{mPa} \cdot \mathrm{s})\end{array}$ & $\begin{array}{c}\text { メートグラス内残存率 } \\
(\%)\end{array}$ & $\begin{array}{c}\text { ディスペンサー内残存率 } \\
(\%)\end{array}$ \\
\hline アタラックス & 200 & $18.3 \pm 4.1$ & $0.15 \pm 0.08$ \\
\hline 単シロップ & 112 & $11.3 \pm 1.7$ & $0.12 \pm 0.04$ \\
\hline アスベリン & 60.6 & $7.5 \pm 1.0$ & $0.12 \pm 0.05$ \\
\hline ムコソルパン & 57.8 & $9.0 \pm 0.8$ & $0.11 \pm 0.05$ \\
\hline
\end{tabular}

a), b) 平均値士標準偏差 $(n=3)$ 
表 3 . 混合シロップ斉の実処方におけるメートグラス 内付着残存率

\begin{tabular}{|c|c|c|c|}
\hline & 処 & 例 & 残存率 $(\%)^{\mathrm{a})}$ \\
\hline Rp. 1 & $\begin{array}{l}\text { アスベリン } \\
\text { ペリアクチン } \\
\text { ムコソルバ } \\
\text { メプチン }\end{array}$ & $\begin{array}{c}2 \mathrm{~mL} \\
3 \mathrm{~mL} \\
3 \mathrm{~mL} \\
4 \mathrm{~mL} \text {. } \\
\text { (朝·夕食後 7日分) }\end{array}$ & $2.84 \pm 0.17$ \\
\hline Rp. 2 & $\begin{array}{l}\text { アスベリン } \\
\text { ムコソルハン } \\
\text { xプチン }\end{array}$ & $\begin{array}{l}3 \mathrm{~mL} \\
5 \mathrm{~mL} \\
5 \mathrm{~mL} \\
\text { (毎食後 7日分) }\end{array}$ & $3.53 \pm 0.24$ \\
\hline Rp. 3 & $\begin{array}{l}\text { ゼスラン } \\
\text { ムコダイン }\end{array}$ & $\begin{array}{c}2 \mathrm{~mL} \\
4 \mathrm{~mL} \\
\text { (朝·夕食後 7日分) }\end{array}$ & $2.32 \pm 0.37$ \\
\hline Rp. 4 & $\begin{array}{l}\text { アスベリン } \\
\text { ムコソルバン }\end{array}$ & $\begin{array}{l}3 \mathrm{~mL} \\
5 \mathrm{~mL} \\
\text { (毎食軩 7日分) }\end{array}$ & $5.53 \pm 0.25$ \\
\hline
\end{tabular}

a)平均值士標準偏差 $(\mathrm{n}=3)$

であり，必ずしも高い粘度を示したシロップ斉(表 1)に 記載されているわけではなかった .ムコソルバンは, 比 較的高い粘度を示したが，IFに粘度や粘性に関する記 載がないこともわかった .このことは，薬剂師がIF だ けではシロップ斉の粘性に関する客観的な情報を得るこ とができない可能性を示唆している .

液斉の製剂学的および物理化学的性質について検討し た例は，いくつか報告されている ${ }^{14-17)}$. 黑田らはニュー トン流体の性質を示すシロップ剂を用いて，ガラス器壁 への薬液付着量と粘度との関連性を明らかにし, 光の付 着量から粘度の予測が可能であることを報告してい る ${ }^{17}$. 保険薬局においても，このような粘度の予測が可
能であれば, 薬斉師は経験や感覚のみならず科学的な根 拠に基づいて調斉手法を確立することができる．しかし ながら，黑田らによるガラス器壁への付着残存量の検討 は，保険薬局の調斉室において実施するには多量の試料 を必要とするなど，克服すべきいくつかの課題が残って いる.乥こでわれわれは, シロップ斉の秤量器具(メー トグラス)に対する付着残存率の単純な評価系を確立し た . 円錐型のメートグラスを水平 , すなわちメートグラ スの注ぎ口側の平面を垂直に維持した際，メートグラス の内部にはシロップ斉が流下するための一定の緩やかな スロープが形成される(図 1) . われわれはこのスロープ を利用して , シロップ剂を投薬びんのなかに一定時間流 下させ , 光の後メートグラスに残存するシロップ斉の質 量を測定することから，メートグラスへの薬液の付着残 存性の指標にした .メートグラス内付着残存率は光れ光 れのシロップ斉の特性に応じた固有の值を示し(図 2)， 付着残存率の高いアタラックス, 単シロップ , ムコソル バンおよびアスベリンにおいては, 弚れらの值か時間の 経過に伴い減少することがわかった(図 3). 実際のシ ロップ剂の調剂においては, メートグラスを一定時間水 平にした後, さらに大きく傾けて薬液の損失を限りなく 少なくするか，メートグラス内に残存した薬液を水など で洗浄して光の洗液を加えるのが一般的である．宮本ら は , ジゴキシンエリキシル剂をモデル剂形として調剂工 程および服用時に生じる薬剂損失について検討してお り，メスシリンダーを約 10 秒間かけて注いだ後，角度 を 45 度とし 5 秒間保った試験系によるシミュレーショ

表 4. インタビューフォーム(IF)における粘度や粘性に関する記述の有無および記載されている主な添加剂

\begin{tabular}{|c|c|c|c|c|c|c|c|}
\hline \multirow{2}{*}{ シロッフ删 } & \multicolumn{2}{|c|}{ 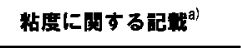 } & \multirow{2}{*}{ 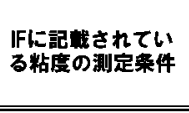 } & \multirow{2}{*}{ 粘性に閉する記述 ${ }^{\mathrm{b} \text { ? }}$} & \multicolumn{3}{|c|}{ 主な添加都 } \\
\hline & $\begin{array}{c}\text { 粘度 } \\
(\mathrm{mPa} \cdot \mathrm{s}) \\
\end{array}$ & $\begin{array}{c}\text { 㨁粘度 } \\
\left(\mathrm{mm}^{2} / \mathrm{s}\right)\end{array}$ & & & 甘味郕 & 粘性の夜体 & その他增粘剂等 \\
\hline アスベリン & $100 \sim 300$ & $x$ & $\begin{array}{l}\text { B型粘度咭, } \\
30 \mathrm{rpm}, 30 \mathrm{sec}\end{array}$ & $x$ & $\begin{array}{c}\text { サッカリンNa } \\
\text { D-ソルビトール }\end{array}$ & プビレングリコール & 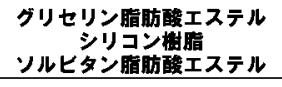 \\
\hline アタラックス & $280 \sim 320$ & $x$ & $20^{\circ} \mathrm{C}$ & $x$ & D-ソルヒトール & プロビレングリコール & カルメロースNa \\
\hline カロナール & $x$ & $x$ & & $x$ & サッカリンNa & $\begin{array}{c}\text { ブロピレングリコール } \\
\text { マクロゴール }\end{array}$ & \\
\hline ゼスラン & $x$ & $12.5 \sim 14.5$ & $\begin{array}{c}\text { ヴロ示’型粘度計 } \\
20 \text { C C }\end{array}$ & 清洞 & D-ソルヒトール & & \\
\hline ノイチーム & $x$ & 3. 30 & & $x$ & D-ソルヒトール & 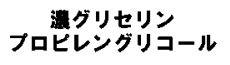 & \\
\hline ペリアクチン & $x$ & 5.99 & $20{ }^{\circ} \mathrm{C}$ & $x$ & $\begin{array}{c}\text { 白棓 } \\
\text { サッカリンa }\end{array}$ & グリセリン & \\
\hline ムコンルパン & $x$ & $x$ & & $x$ & D-ソルヒトトール & グリセリン & ヒドロキシエチルセルロース \\
\hline ムコダイン & $x$ & $x$ & & $x$ & D-ソルヒトトール & & \\
\hline メブチン & $x$ & $x$ & & やp粘桐 & 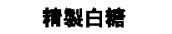 & & \\
\hline
\end{tabular}

a) IF に記載されている粘度および動粘度の単位を本論文で使用している単位に合わせて記載している．×は粘度または動粘度の記載がないことを示 している

b) $\times$ は IF の「剂形の区別及び性状」の頃に粘性に関する記載がないことを示している. 
ンを行っている18).

次に , シロップ剂のメートグラス内付着残存率とレオ ロジー的特性との関係について明らかにするために , シ ロップ斉のレオロジー特性の一つである粘度の測定を試 みた .レオグラムの結果より，アスベリン(塑性流動)を 除くすべてのシロップ剂においてニュートン流動を示す ことが明らかとなった(図 4).レオグラムの傾きから算 出された粘度と付着残存率との間に明らかな相関性 $(\mathrm{y}=$ $0.0823 x+2.2785, r^{2}=0.981$ )が観 察された(図 $\left.5 a\right) . ま$ た, 粘度を密度で除した動粘度においても同樣に, 付着 残存率との間に高い相関性 $\left(y=0.1058 x+2.1346, r^{2}=\right.$ 0.987)か認められた(図 5b) .これらの結果から，メート グラス内薬液残存率からシロップ剂の粘度および動粘度 を推定できることが示唆された . アスベリン , アタラッ クス,ゼスラン ,ノイチーム, ペリアクチンの 5 品目は, IF の粘度または動粘度に関する記載值とほぼ同等の值 であった .

ところで, 試料がニュートン流動を示す場合 , 粘度は いずれのせん断速度においても一定の值を示し，光の值 はレオグラムの傾きから得られる粘度と等しい .これに 対して, 試料が非ニュートン流動を示す場合，粘度はせ ん断速度によって異なる值を示す．今回，われわれはレ オグラムを作成することにより，アスベリンが降伏值を 有する塑性流動を示すことを明らかにし，レオグラムの 傾きから塑性粘度を算出した . 各々のシロップ斉の粘度 を比較する場合には，レオグラムを作成し光の流動特性 をよく見きわめて粘度を比較する必要性が示唆された．

シロップ剂がメートグラス内に付着残存する要因の一 つに, メートグラスのガラス表面とシロップ斉の界面で 生じる相互作用が考えられる. 弚こで, ガラス材質とシ ロップ斉のぬれ性を評価するために, 平らなガラス表面 に滴下したシロップ剂の液滴がガラス板と接触する角度 を測定した．高粘度および高い付着残存性を示したアタ ラックスや単シロップは高い接触角を示したものの, 各 試料の接触角とメートグラス内付着残存率との間には良 好な関係は認められなかった(図 5c).一般にシロップ 剂の秤量器具から投薬びんへの移行性は, 器具表面を流 下する液の粘性と液の器壁に対する“ぬれ”の性質に依 存していると考えられている．しかしながら，器具が メートグラスのようなガラス製である場合においては， 器具表面を流下する液の粘性が主要な因子とされてお り ${ }^{17)}$, 今回のメートグラス内付着残存率と粘度の関係か ら得られた知見はこれを支持するものであった 。

本検討で使用したシロップ斉のなかで , アタラック ス , アスベリンおよびムコソルバンは $50 \mathrm{mPa} \cdot \mathrm{s}$ 以上の 高い粘度を示した(表 1).これらの製剂には白糖やD-ソ ルビトールなどの甘味剂, グリセリンやプロピレングリ コールなどの粘稠性液体のほか, カルメロースナトリウ
ム(アタラックス) , ヒドロキシエチルセルロース(ムコソ ルバン)およびシリコン消泡剂(アスベリン)などの粘性を 示す添加剂 ${ }^{19}$ が配合されているため(表 4)，他のシロッ プ剂に比較して高い粘度を示したものと考えられた．

われわれは本検討で用いたシロップ斉のなかで，アタ ラックス, アスベリン , 単シロップおよびムコソルバン の粘性が高く，メートグラス内に残存しやすいことを日 頃の業務から感覚的に認識している．一般にこれらの薬 液をメートグラスから投薬びんへ移行させるときは , 先 に述べたようにメートグラスをさらに大きく傾けるか， メートグラス内に残った薬液は少量の水で洗い, 洗液を 投薬びんに加える1などの対応をより慎重に時間をかけ て行うことが必要となる．また，秤量直前にあらかじめ 乾燥したメートグラス内を水で軽くなじませることも薬 液の粘性をわずかに低下させ，流動性を高め，損失を少 なくできる方法の一つである .メートグラス内薬液残存 率と比較して，ディスペンサー内薬液残存率は，速やか に損失なく投薬びんへ移行させることが可能であった (表 2) . この結果より，ディスペンサーは粘稠性の高い シロップ剂を調剂するために有用であることが検証でき た .これらの薬剂のメートグラス残存率は 6〜 7\% 以上 であり(図 2), 粘度は $57 \mathrm{mPa} \cdot \mathrm{s}$ 以上の範囲であることか ら(表 1), 少なくとも 50〜 $60 \mathrm{mPa} \cdot \mathrm{s}$ 程度の粘度を有する シロップ剂を調剂する際には, 正確性および効率性の観 点からディスペンサーの使用を考慮する必要があること が示唆される .

液体食品の口内重厚感と光の食品の粘度との間には, 一定の関係が成立することが知られており ${ }^{20)}$, 食品の粘 度が光のおいしさや飲みやすさに大きく関与することが 推察される. 石坂らは, シロップ剂の動粘度が 15〜20 $\mathrm{mm}^{2} / \mathrm{s}$ 以上であると嚥下しづらくなり，服用性に影響を 及ぼすことを報告している21). 服用性の観点からみれ ば，通常のシロップ剂は混合で処方されるケースが多く みられ，混合剂での粘性の把握も重要である．製薬企業 における製剂設計時には他剂との配合調剂を考慮するこ とはほとんどないため ${ }^{22)}$, 混合剂の粘性に関する情報は 乏しい．㫕こで，われわれは当薬局で受ける実処方 4例 についてメートグラス内付着残存率を測定することから 動粘度の推定を試みた . 表 3 に示すように，低粘度のシ ロップ剂とともに高粘度のアスベリンおよびムコソルバ ンが含まれている処方例(Rp .1およびRp 2)や高粘度シ ロップ剂の含まれていない処方例(Rp .3)においては付着 残存率が 3.5\% 以下であり，図 $5 b$ から動粘度は 15 $\mathrm{mm}^{2} / \mathrm{s}$ 以下と推定された . しかしながら , アスベリンと ムコソルバンのみの処方例(Rp .4)については残存率が $5.5 \%$ であり，嚥下しにくくなる動粘度 $\left(34 \mathrm{~mm}^{2} / \mathrm{s}\right)$ とな ることが推定された . シロップ斉の粘性は患者の服用性 だけでなく，保護者の取り扱いやすさにも影響を及ぼす 
ことが考えられることから，計量カップによる損失につ いても今後明らかにしていく必要がある .

以上の結果より，シロップ斉のメートグラス内薬液残 存率と光の粘度との間に明らかな相関か認められた . 正 確性および効率性の観点から，少なくとも50〜60 $\mathrm{mPa} \cdot \mathrm{s}$ 程度の粘度を有する粘稠性シロップ斉の調剂に は, メートグラスよりディスペンサーの使用か望ましい ことが示唆された．本研究におけるシロップ斉の粘性に 関する評価は，服用性の観点からも非常に有用な情報と なることが期待され，科学的な根拠に基づいた調斉手法 の確立に貢献するものと考えられる .

謝辞 本研究におけるレオロジー特性に関して有益な御助 言をいただいた, 日本大学薬学部薬品物理化学研究ユニット 橋崎要博士および井上元基修士に感謝いたします．

\section{引用文献}

1) 日本薬剂師会編，“第十二改訂調剂指針”薬事日報 社，東京，2006，pp.118-119.

2) 日本薬局方解説書編集委員会編，“第十五改正日本 薬局方解説書”，廣川書店，東京，2006，B-320.

3) 日本薬局方解説書編集委員会編，“第十五改正日本 薬局方解説書”，廣川書店，東京，2006，B-358.

4) 石井淑夫, 小石眞純, 角田光雄編 “”ぬれ技術ハン ドブック - 基礎・測定評価・データ - "テクノシス テム, 東京 , 2001 , p.19.

5) アスベリン錠 $10 \cdot 20$ ・アスベリン散 10\%・アス ベリンドドライロップ $2 \%$ ・アスベリンシロシップ $0.5 \%$ ・アスベリンシロップ「調剂用」 $2 \%$ インタ ビューフォーム，田辺製薬株式会社，2005年 7 月．

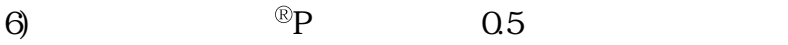
フォーム,ファイザー製薬株式会社,2006 年 10 月。

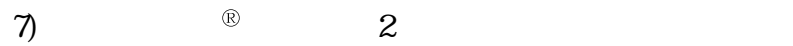
昭和薬品化工株式会社, 2005 年 6 月.

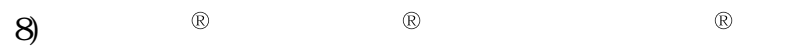
用細粒 0.6\% インタビューフォーム, 旭化成ファー マ株式会社，2005年 7 月。

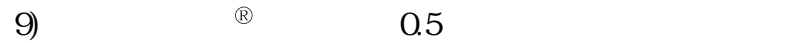

ム, エーザイ株式会社，2006 年 7 月 .

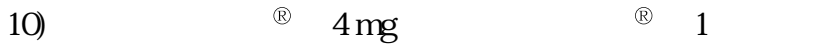
リアクチンシロップ $0.04 \%$ インタビューフォー 厶, 萬有製薬株式会社, 2006 年 8 月。

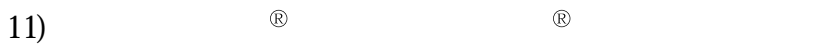
ン ${ }^{\circledR}$ シップ・ 小巟用ムコソルバン ${ }^{\circledR}$ DS 1.5\% · DS 3 \%・ムコソルバン $\mathrm{L}$ カプセルインタビューフォー ム, 帝人ファーマ株式会社, 2007 年 7 月 .

12）ムコダイン錠 $250 \mathrm{mg} \cdot 500 \mathrm{mg}$ ・ムコダイン ${ }^{\circledR}$ 細粒・

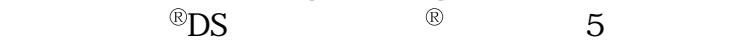
ビューフォーム，杏林製薬株式会社，2006年 11 月。

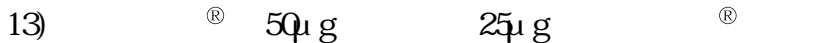

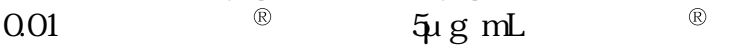
ライシロップ $0.005 \%$ インタビューフォーム , 大塚 製薬株式会社，2006 年 8 月。

14）中垣正幸, 河村成男, 懸濁性シロップ剂の物理化学 的研究(第 3報)スルファミン類の界面膜電位につい て, 薬学杂隹誌, 85，894-898(1965).

15) 中垣正幸, 河村成男, 懸濁性シロップ剂の物理化学 的研究(第 6 報)カルボキシメチルセルロースナトリ ウム熫糖水溶液の粘性挙動について, 薬学杂倠誌, 88 , 852-856 (1968).

16)青木大, 福地坦, 笠原伸元, 石田定広, 三浦泰彦, 蔵野雅庸，懸濁シロップ剂の製剂学的検討：シロッ プ用抗生物質粉末斉の懸濁性, 薬剂学, 32, 159-164 (1972).

17) 黑田稔, 広田貞雄, シロップ剂の器壁付着の数量的 評価, 薬斉学, 37, 152-158 (1977).

18）宮本昌二, 鈴木勝, 幸田幸直, 調剂工程および服用 時の薬剂損失 - ジゴキシン製剂をモデルにして - , 病院薬学 , 25, 292-298 (1999).

19) 日本医薬品添加剂協会編，“医薬品添加物事典 2005”，薬事日報社，東京，2005，pp.1-335.

20) 西成勝好, 食とレオロジー,日本レオロジー学会誌, 31 , 41-50 (2003).

21) 石坂敏彦, 岡田祥恵, 获本絵里, 向井淳治, 徳山絵 生, 内田享弘, Prednisolone 散内服時の最適苦味抑 制法について 第 17 回日本医療薬学会講演要旨集, 339 , (2007).

22) 石坂隆史, シロップ剂を中心とした内用液剂の配合 変化について ,プライマリ・ケア ,27,36-43 (2004). 